\title{
The Reception of Geoffrey of Monmouth in the Crown of Aragon
}

\author{
Nahir I. Otaño Gracia
}

The reception of Geoffrey of Monmouth in Catalonia and the Crown of Aragon demonstrates that the De gestis Britonum was an important component in the creation of a textual, historical, and mythical Catalan identity. Despite the dearth of primary materials available, scholars have found information derived from the $D G B$ in several texts produced by the Crown of Aragon. ${ }^{1}$ These texts include a partial translation into Catalan of the $D G B$ as well as other historiographical records and the Crónicas of Ramon Muntaner (1325-28). The use of the $D G B$ in these contexts connect Geoffrey's work with the creation of a mythical and historical lineage for the Crown of Aragon. Some scholars, including myself, suggest that the use of the $D G B$ in the $13^{\text {th }}$ and 14th centuries helped legitimize the ideologies of expansion of the Crown of Aragon. ${ }^{2}$ The historiographical records follow a pattern from other Christian Peninsular texts to create a Spanish genealogy, and the Crónicas, an account of Catalan chivalry, aim to demonstrate Catalan superiority. ${ }^{3}$ This entry contextualizes

1 I use Ernst Kantorowicz's definition of the Crown, which does not only include the king but those who work alongside the king to protect the kingdom. He defines the Crown as a "composite body, an aggregate of the king and those responsible for maintaining the inalienable rights of the Crown and the kingdom. As a perpetual minor, the Crown itself had corporational character - with the king as its guardian, though again not with the king alone, but with that composite body of king and magnates who together were said to be, or to represent, the Crown"; E.H. Kantorowicz, The King's Two Bodies: A Study in Medieval Political Theology, Princeton, 1957, repr. 1997 with a new preface, p. 381.

2 See D. Abulafia, "La Corona de Aragón en la Época de Tirant Lo Blanc, 1392-1516", in E. Mira (ed.), Joanot Martorell y el otoño de la Caballería, Valencia, 2011, pp. 47-6o, at p. 49; J. Aurell, Authoring the Past: History, Autobiography, and Politics in Medieval Catalonia, Chicago, 2012, pp. 192-93; and J. Izquierdo, "Traslladar la memòria, traduir el món: la prosa de Ramon Muntaner en el context cultural i literari romànic", Quaderns de filologia. Estudis literaris 8 (2003), 189-244 for some examples of the use of Arthuriana in Catalonian affairs. My own forthcoming research on Catalan Arthurian manuscripts shows that texts such as La Faula (1370-74), Curial e Güelfa (1440-6o), and Tirant lo Blanc (1490) also claim that Catalan knights are better than Arthurian knights in order to support chivalric ideologies of expansion.

3 The terms Iberia, Al-Andalus, and Spain are interrelated concepts that define different aspects of the Peninsula. Iberia corresponds to the entire Peninsula. Al-Andalus encompasses 
the reception of the $D G B$ in the history of the Crown of Aragon and delves into the extant materials and their role in Catalan affairs.

The reception of Geoffrey of Monmouth must be understood through several geographical frameworks. They include the south of France (known as Occitania), the Iberian Peninsula, and the Mediterranean world. ${ }^{4}$ The similar cultures of Occitania and Catalonia in the 12th century and the easy movement of the Occitan and Catalan troubadours throughout the Pyrenees means that the troubadours from both Occitania and Catalonia treated the literature very similarly. 5 The integration of Catalonia and the kingdom of Aragon combined the maritime and inland territories of the Aragon courts and the Catalan dynasty, creating the Crown of Aragon and expanding the territories of the Catalans into the Peninsula and the Mediterranean. ${ }^{6}$ The acquired status of the Crown as an up-and-coming kingdom redefined the ways the Catalan courts understood themselves. The Deeds of the Counts of Barcelona (Gesta comitum Barcinonensium, 1180), for example, was written to create a Catalan genealogy as a response to the Catalan courts' central position in Occitania, the Peninsula, and the Mediterranean. ${ }^{7}$ The Albigensian Crusade of 1212, however, changed the needs of the Crown of Aragon once again and they began to prioritize expansion in the Mediterranean, breaking the ties that united the Crown of Aragon with Occitania. ${ }^{8}$

Muslim-controlled territories between 711-1492. Spain encompasses Christian-controlled territories now associated with the Spanish state (Castile, Navarre, Aragon, Catalonia, and so on). See T.F. Glick, Islamic and Christian Spain in the Early Middle Ages, Princeton, 1979, pp. 13-15.

4 The introduction of Arthurian motifs to Catalan literature and culture begins with the cultural and political connections between Catalonia and Occitania. See A.J. Kosto, Making Agreements in Medieval Catalonia: Power, Order, and the Written Word, 1000-1200, Cambridge, 2001, p. 9; L. Patterson, The World of the Troubadours, Cambridge, 1993, pp. 1-3; L. Soriano Robles, "The Matière de Bretagne in the Corona de Aragón", in D. Hook (ed.), The Arthur of the Iberians: The Arthurian Legends in the Spanish and Portuguese Worlds (Arthurian Literature in the Middle Ages, 8), Cardiff, 2015, pp. 165-86, at p. 162.

5 For the francophone reception of Geoffrey, see Chapter 20, which indicates that there is no extant Occitan reception of Geoffrey.

6 In 1137 Ramon Berenguer IV, Count of Barcelona (1131-62), was betrothed to Petronilla of Aragon (1136-76), gaining control not only of the territories of the counts of Barcelona, but also of the kingdom of Aragon. Alfonso II (1162-96), child of Petronilla and Ramon, became the first king of what is known as the Crown of Aragon.

7 See J. Aurell, "From Genealogies to Chronicles: the Power of the Form in Medieval Catalan Historiography", Viator 36 (2005), 235-64, at p. 238; and S.M. Cingolani, "De historia privada a historia pública y de la afirmación al discurso: Una reflexión en torno a la historiografía medieval catalana (985-1288)", Talia Dixit 3 (2008), 51-76.

8 M. Vanlandingham, Transforming the State: King, Court and Political Culture in the Realms of Aragon (1213-1387), Leiden, 2002, p. 9. 
The inclusion of the $D G B$ in the textual production of the Crown of Aragon is discernable after the break between Occitania and Catalonia because the Crown saw Spain and the Mediterranean as their new sources for European growth economically and culturally. This historical context serves as a backdrop for the reception of Geoffrey of Monmouth in the Crown of Aragon. The Catalan Crown saw itself as a young kingdom, and because they saw themselves as young, they began to build their own historical and mythical past as a response to their relatively new position within Spanish and European affairs. In addition, it is also imperative to know that the connection between the history of the Crown of Aragon and Spain is also the reason for the dearth of materials for analysis. Both the Inquisition and the advent of the printing press greatly diminished the extant medieval texts available for study in Spain. The latter used manuscripts of the common variety for bookbinding; the former made keeping texts of entertainment dangerous. The end result is that many manuscripts were lost, including manuscripts that would have included the work of Geoffrey of Monmouth, making any assessment of the Catalan reception of the text incomplete. ${ }^{9}$

Despite the difficulties in assessing the reception of Geoffrey of Monmouth's $D G B$ in the Crown of Aragon, the impact of the text is discernable. The Anales navarro-aragoneses, also known as the Crónicas navarras, was written c.1196 in Latin and Navarre-aragonese. ${ }^{10}$ The historiographical text mentions the death

$9 \quad$ J.M. Lucía Megías explains that "the success of the printed romances of chivalry, which would become one of the staples of the burgeoning Hispanic publishing industry, would lead to many of the common chivalric manuscript codices being replaced by printed editions ... To this factor, which we may class as an aesthetic consideration, there was added another, as the Counter-Reformation gave impetus to methods of control over what was published and what was kept in the noble libraries of Spain: there was an increasing tendency to remove the literature of entertainment from these collections" ("The Surviving Peninsular Arthurian Witnesses: A Description and an Analysis", in Hook (ed.), The Arthur of the Iberians, pp. 33-57, at pp. 50-51). The loss of Catalan Arthurian texts becomes apparent when we compare the extant manuscripts of Arthurian romance with their mentions in the chancery registers. The Catalan registers mention five copies of Merli (from 1383-1459), 18 copies of Lançalot (from 1319-1488), 13 copies of Saint Graal (from 1342160o), three copies of Mort Artu (from 1349-1422), and 22 copies of Tristan en Prose (from 1315-1467). By contrast the extant Catalan manuscripts of these romances include no copies of Merli, two copies of Lançalot, two copies of Saint Graal, one of Mort Artu, and three of Tristan en Prose (S.M. Cingolani, 'NNos en leyr tales libros trobemos plazer e recreation'. L'estudi sobre la difusió de la literatura d'entreteniment a Catalunya els segles XIV i XV", Llengua \& Literatura 4 (1990-91), 39-127, at pp. 74-92).

10 The Anales navarro-aragoneses were written in the kingdom of Navarre which neighbors the kingdom of Aragon. The use of Navarre-aragonese is a testament to the connections between the two kingdoms in the early history of the Peninsula. 
of Arthur and gives the same date as the DGB. The Anales state that "It was in the year D.LXXX that King Arthur and Mordret made battle in Quibleno."11 It is clear that the information derives from Geoffrey's work (either from a copy of the text or an indirect source). The Anales navarro-aragoneses inspired both directly and indirectly Christian Iberian historiographic tradition. Historiographic texts from the Christian courts of the Peninsula such as Fuero de Navarra (c.1205), The Book of Kings (Liberregum) or Chronicon Villarense (c.1211), Anales toledanos primeros (c.1217), and General estoria (c.1270-80) all mention the battle between Arthur and Mordred using Geoffrey's dating of the event. ${ }^{12}$

The role of the $D G B$ as part of Catalan historiography is apparent in Paris, Bibliothèque nationale de France, esp. $13\left(1385^{-1430}\right)$ which is a compilation of historiographic texts, including Gauchier de Denain's Compendi historial, Rodrigo Jiménez de Rada's Crónica d'Espanya, and Jaume Domènech's Genealogia dels reis d'Aragó. Folios 83v-97v in particular contain a translation of the $D G B$ into Catalan. ${ }^{13}$ Pere Bohigas argues that this compilation of historiographic texts is one of the sources used by the Catalan chronicler Juan Fernández de Heredia (1310/15-1396), who incorporates parts of the $D G B$ into the Grant Crónica d'Espanya found in Madrid, Biblioteca Nacional de España, 10133. ${ }^{14}$ Fernández de Heredia was Master of the Order of St John of Jerusalem and an influential force in the Crown of Aragon and Europe in general. ${ }^{15}$ Fernández de Heredia continues the tradition of other agents of the Christian courts of the Peninsula who used the $D G B$ as part of their historiography.

11 "Era D.LXXX aynos fizo la bataylla el rey Artus con modret en Quibleno." My translation. Cited from C. Alvar, "The Matter of Britain in Spanish Society and Literature from Cluny to Cervantes", in Hook (ed.), The Arthur of the Iberians, pp. 187-270, at p. 234. See also Corónicas navarras, ed. A. Ubierto Arteta (Textos Medievales, 14), Zaragoza, 1989, p. 40.

12 As in the British Isles, the $D G B$ was incorporated into chronicles and annals throughout the Peninsula. See Chapter 25 of this volume as well as P. Gracia, "Arthurian Material in Iberia", in Hook (ed.), The Arthur of the Iberians, pp. 11-32, at pp. 15. The Anales Toledanos I give the same date as the $D G B$ but change Arthur's name to Rey Zitus. The annal states that "Lidió el Rey Zitus con Modret su sobrino en Camblenc, Era DLXXX", "King Zitus fought with his nephew Modret in Camblenc, it was DLXXX" (Anales Toledanos I, ed. E. Flórez, España Sagrada (XXIII), Madrid, 1767, p. 381, my translation).

13 P. Bohigas, Sobre manuscripts $i$ bibliotheques (Textos i Estudis de Cultura Catalana, 10), Barcelona, 1985, pp. 123-32, 180-203; Soriano Robles, "Matière de Bretagne", p. 170.

14 Bohigas, Sobre manuscripts $i$ bibliotheques, p. 179. A digital copy of the manuscript Grant Crónica d'Espanya is available online at <http://bdh-rd.bne.es/viewer.vm?id= oooooo8341\&page $=1>$ (accessed 16 March 2018).

15 L. Badia and I. Grifoll, "Language: From the Countryside to the Royal Court", in F. Sabaté (ed.), The Crown of Aragon: A Singular Mediterranean Empire (Brill's Companions to European History, 12), Leiden, 2017, pp. 361-86, at pp. 38o-81. 
Regarding the Crown of Aragon in particular, Fernández de Heredia used the $D G B$ to solidify a mythical and historical past for the Crown.

The use of Geoffrey's work in historiographic records is an example of the ways the Crown of Aragon enhanced its standing within a European setting. The Crónicas of Ramon Muntaner and Bernat Desclot (1283-88) continue the tradition of using the $D G B$ in the construction of a Catalan identity. ${ }^{16}$ Both texts use $D G B$ and Arthuriana to enhance the narration of Jaume's birth found in his own Crónica. ${ }^{17}$ They specifically use the birth of Arthur in the $D G B$ and the birth of Galahad in the Vulgate to create an association between Jaume, Arthur, and Galahad as the best kings/knights in Christian Europe in order to solidify Jaume's claim to the throne. ${ }^{18}$ Muntaner's Crónica in particular substitutes Jaume for Arthur and the Duke of Tintagel for Uther Pendragon. ${ }^{19}$

Although these examples are few, they demonstrate that the $D G B$, especially the character of Arthur as represented in the $D G B$, was one of the ways that the Crown of Aragon created their own historical and mythical past in order to claim their own Europeanness. This is consistent with the use of Arthuriana in the Catalan courts to claim that the Crown of Aragon was the future of chivalric conquest in Europe.

16 J. Aurell, Authoring the Past, pp. 40-42.

17 Known in English as James I the Conqueror, Jaume was born in 1198. In 1213 he became king of the Crown of Aragon after his father, Piere le Catholic (1196-1213), died at the battle of Muret. James I is known for his ambitious policies of expansion in the Peninsula and the Mediterranean Sea. Following his grandfather's footsteps, Alfonso II, who commissioned the Gesta comitum and gave his patronage to the troubadour poets in order to create a Catalan genealogy, Jaume dictates El Llibre dels fets del rei en Jaume ("The Book of the Deeds of King James"), the first of the Quatre Grans Chròniques ("Four Great Chronicles"), to celebrate the deeds of the Crown of Aragon. For more information see J. Aurell, Authoring the Past, pp. 39-54.

18 P. Bohigas, Aportació a l'estudi de la literature catalana, Monserrat, 1982, p. 28o; J.M. Pujol, La memòria literària de Joanot Martorell:Models iscriptura en el 'Tirant lo Blanc', Barcelona, 2002; A.G. Elliot, "The Historian as Artist: Manipulation of History in the Chronicle of Desclot", Viator 14 (1983), 195-209.

19 M. Montoliu, "Sobre els elements èpics, principalment asturians, de la Crònica de Jaume I", in n.n. (ed.), Homenaje ofrecido a Menéndez Pidal: miscelánea de estudios lingüísticos, literarios e históricos, 3 vols., Madrid, 1924, vol. 1, pp. 698-712. 